\title{
Correlation between clinical findings, mast cell count and interleukin 31 immunostaining in the skin of dogs with atopic dermatitis
}

\author{
Bárbara Hess Rodrigues Gonçalves ${ }^{1 *}$ Bruna Dantas Matos $^{2}$ - Mariana Batista Rodrigues Faleiro ${ }^{3}$ \\ Emmanuel Arnhold ${ }^{4}$ Moema Pacheco Chediak Matos ${ }^{5}$ \\ Ana Paula Iglesias Santin ${ }^{5}$ Veridiana Maria Brianezi Dignani de Moura
}

${ }^{1}$ Hospital Veterinário São Francisco de Assis, 74835-100, Goiânia, GO, Brasil. E-mail: berbaraveterinaria@live.com. "Corresponding author. ${ }^{2}$ Medicina Veterinária, Escola de Veterinária e Zootecnia (EVZ), Universidade Federal de Goiás (UFG), Goiânia, GO, Brasil. ${ }^{3}$ Faculdade União de Goyazes (FUG), Trindade, GO, Brasil. ${ }^{4}$ Departamento de Zootecnia, Escola de Veterinária e Zootecnia (EVZ), Universidade Federal de Goiás (UFG), Goiânia, GO, Brasil. ${ }_{5}^{5}$ Departamento de Medicina Veterinária, Escola de Veterinária e Zootecnia (EVZ), Universidade Federal de Goiás (UFG), Goiânia, GO, Brasil.

ABSTRACT: In this study the correlation between the clinical score, mast cell count and interleukin 31 (IL-31) immunostaining in the skin of dogs with atopic dermatitis was determined. A total of 31 dogs of different breeds, from one to eight years of age, were chosen for the study. The 20 females and 11 males were categorized based on the CADESI-4 system, as having discrete, moderate or marked atopic dermatitis. Skin samples were collected from the axillary and interdigital regions and stained with hematoxylin and eosin for cytohistomorphological analyses and toluidine blue to evaluate the mast cell counts, and immunohistochemistry for the IL-31 immunostaining. Animals revealing higher atopic dermatitis scores had greater numbers of mast cells and IL-31 immunolabeled cells. More numbers of cells immunolabeled for IL-31 were evident in the axillary skin compared with the interdigital skin in dogs having this condition. A correlation was identified between the clinical scores and mast cell numbers in the interdigital region, as well as between the clinical scores and number of cells immunolabeled for IL-31 in the axillary area. A correlation was also reported between the mast cell numbers and IL-31 immunolabeled cells only in the axillary skin, and none in the interdigital regions. It was thus concluded that the mast cells and IL-31 are involved in the pathogenesis of the canine atopic dermatitis (CAD), as well as lymphocytes and plasma cells. It was also observed that the higher the degree of clinical severity of the disease, the more the numbers of mast cells and IL-31 in the skin of those animals suffering from CAD, which implies the influence of these immunological constituents on the genesis of pruritus and disease progression.

Key words: canine allergy, pro-inflammatory cytokine, toluidine blue.

Correlação entre achados clínicos, contagem de mastócitos e imunomarcação de interleucina 31 na pele de cães com dermatite atópica

RESUMO: Este estudo avaliou a correlação entre o escore clínico, a contagem de mastócitos e a imunomarcação de interleucina 31 (IL-31) na pele de cães com dermatite atópica. Foram selecionados 31 cães de diferentes raças, com idade entre um e oito anos, sendo 20 fêmeas e 11 machos, divididos em discretamente, moderadamente e acentuadamente acometidos por dermatite atópica segundo o sistema CADESI-4. Amostras da pele das regiões axilar e interdigital foram colhidas e submetidas às colorações de hematoxilina e eosina para a avaliação citohistomorfológica e azul de toluidina para a contagem de mastócitos, bem como a técnica de imunoistoquímica para a imunomarcação de IL-31. Os animais com maior escore de dermatite atópica apresentaram maior número de mastócitos e de células imunomarcadas para IL-31. Houve maior número de células imunomarcadas para IL-31 na pele da axila em relação à interdigital nos cães com a doença. Foi constatada correlação entre o escore clínico e a quantidade de mastócitos no interdígito, bem como entre o escore clínico e a quantidade de células imunomarcadas para IL-31 na axila. Também foi verificada correlação entre a quantidade de mastócitos e células imunomarcadas para IL-31 na pele da região axilar, mas não da interdigital. Conclui-se que mastócitos e a IL-31 estão envolvidos na patogenia da DAC, assim como linfócitos e plasmócitos. Também, quanto maior o grau de severidade clínica da doença, maior a quantidade de mastócitos e IL-31 na pele dos animais com DAC, o que remete à influência desses componentes imunológicos na gênese do prurido e progressão da doença.

Palavras-chave: alergia canina, citocina pró-inflamatória, azul de toluidina.

\section{INTRODUCTION}

Canine atopic dermatitis (CAD), an inflammatory, pruritic and chronic dermatopathy is recurrent and strikes nearly $15 \%$ of the canine population (OLIVRY, 2001). Characterized by multifactorial pathophysiology, knowledge about CAD continues to be obscure, both in humans and animals (WOLF, 2012). Apart from the loss of the tegmental barrier function, $\mathrm{CAD}$ pathogenesis is 
associated with skin sensitization and hyperreactivity to environmental allergens, trophallergens, microbial antigens and irritants (OLIVRY, 2010).

Dogs with this condition reveal erythema and pruritus in specific body sites (HENSEL, 2015). The pruritus-induced lesions are observed in the skin folds and ventral surfaces of the body, particularly in the axillary, interdigital, and inguinal regions, as well as the inner part of the auricular pavilions and periocular and perioral portions. Erythema, self-induced alopecia, excoriation and dyskeratoses are some of the common dermatological indicators (FAVROT, 2010).

CAD is diagnosed from the clinical findings, anamnesis and exclusion of other pruritic diseases (FAVROT, 2010), since there are no specific tests available. Assessment of the allergen-specific $\operatorname{IgE}$ is regarded as less significant and, therefore, hardly ever utilized for the diagnosis of atopic dermatitis, as sometimes dogs affected with CAD do not show positive responses to the test (PUCHEU-HASTON, 2015).

Evaluation of the intensity of the disease and severity in a CAD-affected dog is essential for suitable clinical and therapeutic treatment. Considering this, a system of identification and mapping of the skin lesions, CADESI (Canine Atopic Dermatitis Extent and Severity Index), was proposed to enable veterinarians to observe the dermatological changes in specific anatomical sites of the affected animals and classify them according to the intensity of the symptoms and lesions (OLIVRY, 2014).

The pathogenesis of pruritus in CAD includes both extrinsic and intrinsic factors and is partly linked to the $\mathrm{T}$ lymphocyte-mediated response (ABBAS, 2006) besides the other inflammatory mediators, like the cytokines and chemokines (MURPHY, 2010). The mononuclear cells, mainly the type $\mathrm{T}$ helper lymphocytes, produce the Interleukin-31 (SPERGEL, 1999). It is highlighted here due to its significance in the pathogenesis of $\mathrm{CAD}$ as its expression is related to the increase in the lesion scores during clinical evaluation (DILLON, 2004), and involvement of the neurogenic route of pruritus (GONZALES, 2016).

The aim of this study was to correlate the extent and intensity of the symptoms and lesions with the number of mast cells and the immunolabelling of IL-31 in the skin of dogs affected with atopic dermatitis.

\section{MATERIALS AND METHODS}

Animals routinely visiting the attending clinics, hospitals and clinics in the city of Goiânia,
State of Goiás, Brazil, were selected for the study. Among these, dogs were selected ranging from one to eight years, identified as having atopic dermatitis (after ruling out other allergic skin conditions), and at least five of the criteria proposed by FAVROT (2010) (Table 1). Three healthy dogs in the age range of one to eight years and mixed-breed were also selected to be used as the control group for the clinical, macroscopic and microscopic variables investigated. They were given thorough a physical examination to confirm good health status. Only those animals without a history of recent disease and with no apparent changes related to the general state, as well as showing no evidence of dermatological alterations were selected.

On the other hand, were eliminated from the study animals going through therapy which could interfere with the cutaneous metabolism, such as glucocorticoids or antihistamines, as well as those with systemic diseases that could alter the test results. The owners of the animals affected with atopic dermatitis as well as those of the control group were informed about the research, especially the objectives, procedures and participation of their dogs. After clarifications were made, the owners gave signed consent.

The dogs affected with CAD were assessed for cutaneous changes associated with erythema, lichenification, excoriation and alopecia at the anatomical sites listed: perilabial region, inner region of the auricular pavilions, axillary regions, distal areas of the limbs, anticubital and carpal flexures, flanks, inguinal regions, abdomen, perineum and ventral face of the tail. The variables were assessed for extent and severity, with negative (0), discrete (1), moderate (2),

Table 1 - Criteria to support the clinical diagnosis of canine atopic dermatitis according to FAVROT et al., (2010).

\begin{tabular}{|c|c|}
\hline Score & Description \\
\hline 1 & $\begin{array}{l}\text { Beginning of the first clinical signs prior to three } \\
\text { years of age }\end{array}$ \\
\hline 2 & $\begin{array}{l}\text { Animal stays for the most part of the day in a } \\
\text { domestic home environment }\end{array}$ \\
\hline 3 & $\begin{array}{l}\text { Pruritus as the first clinical sign and good response } \\
\text { to corticosteroids }\end{array}$ \\
\hline 4 & Development of chronic or recurrent pyoderma \\
\hline 5 & $\begin{array}{l}\text { Impingement of the distal extremities of the thoracic } \\
\qquad \text { limbs }\end{array}$ \\
\hline 6 & Ear pinning \\
\hline 7 & Margins of ears unaffected \\
\hline 8 & Dorsal and non-stressed lumbar regions \\
\hline
\end{tabular}


and severe (3) scores being allocated based on the Canine Atopic Dermatitis Extent and Severity Index, version 4 (CADESI-4), using the photographic model of OLIVRY et al. (2014) (Figure 1).The data were noted in a dermatological evaluation form, and always by the same evaluator. The values assigned during the assessment of the lesions were added up and the total was transformed into a clinical score for lesion extent and severity variable, with the dogs being categorized as discretely, moderately or severely compromised by CAD when the scores rose to the range of 10-34, 3559 and above 60 , respectively.

Utilizing the criteria adapted from HILL (2007) as well as with the data gathered from the owners who completed a scale based on the observations of the manifestation of pruritus, the degree of pruritus in each animal was ascertained. The pruriginous manifestation score was given as one (1) when the dog displayed no itching while eating, playing or being distracted (discrete); it was two (2) when the dog exhibited pruritus at night and during times of idleness, but not during eating, playing or being distracted (moderate); and three (3) when the animal exhibited itching most of the time, including at night, as well as during eating, playing, exercising, or when distracted (severe).

Skin samples were harvested from the control $\operatorname{dogs}$ and from those with CAD for microscopic analysis. The samples were taken from the axillary and interdigital regions of the thoracic limbs, as these are the regions known to be with pruritus early in CAD (FAVROT, 2010). The

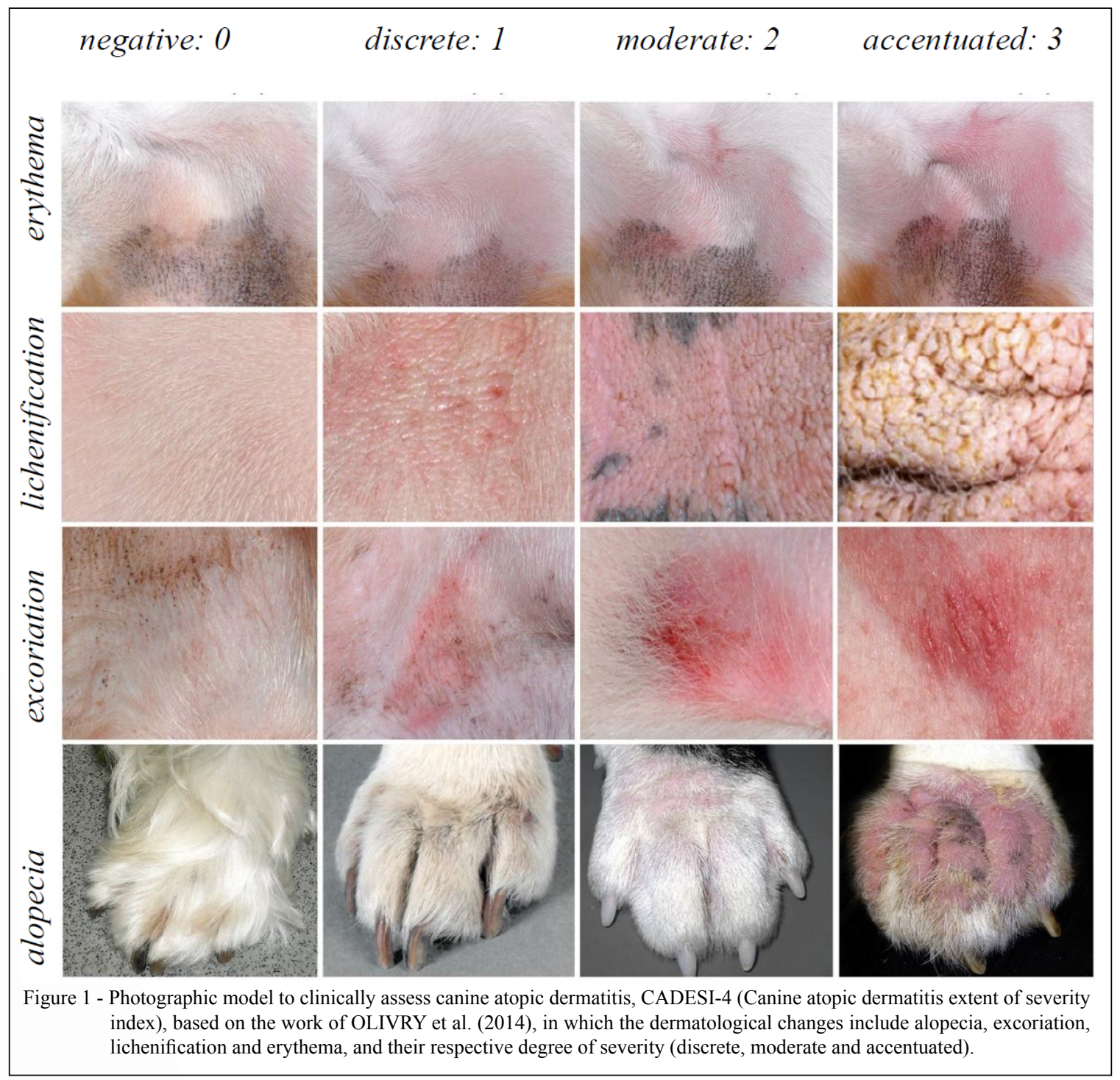

Ciência Rural, v.48, n.9, 2018. 
harvesting procedure was done at a single sitting after the clinical diagnosis of CAD and the establishment of the lesion scores. The dogs were anesthetized using propofol $(5 \mathrm{mg} / \mathrm{kg})$, maintained with isoflurane and subjected to the haircut in the harvest sites. The skin samples were removed using a $6 \mathrm{~mm}$ in diameter punch, fixed in $10 \%$ buffered formalin solution for 24 hours and then maintained in $70 \%$ alcohol until the time of processing, embedding in paraffin and preparation of the histological sections for histopathological (HE and toluidine blue) and immunohistochemical evaluations.

To the mast cells count the toluidine blue staining was performed, which allowed this cellular type identification by the metachromatic cytoplasmic granules. Counting was done at 400x magnification, in 15 randomly selected fields, representative of the expanse of the cutaneous samples.

To the immunohistochemical analysis $3 \mu \mathrm{m}$ sections were obtained, distended on charged slides $\left(\right.$ StarFrost ${ }^{\circledR}$ ) and maintained at $56^{\circ} \mathrm{C}$ for $24 \mathrm{~h}$. They were then subjected to deparaffinization and hydration followed by 15 minutes of immersion in the endogenous peroxidase $\left(8 \% \mathrm{H}_{2} \mathrm{O}_{2}\right)$. Next, antigen retrieval was performed using a buffer solution (DIVA Decloaker, Biocare Medical, \#DV2004LX), in water bath for 30 minutes at $97^{\circ} \mathrm{C}$. Using a specific solution (Kit Easylink One, Easypath, \#EP-1220506) the non-specific reactions were blocked for five minutes at room temperature. Slides were then incubated in a humid chamber for 18 hours at $4{ }^{\circ} \mathrm{C}$ with anti-IL31 antibody (Abcam, \#ab102750) diluted at 1:200. The sections were incubated using the signal amplification system (Kit Easylink One, Easypath, \#EP-12-20506), following the manufacturer's recommendations. A diaminobenzidine solution (DAB) was added, followed by counterstaining with Meyer's hematoxylin to visualize the reaction. Finally, the sections were dehydrated and cleared in xylene and the slides were assembled with synthetic resin and a coverslip to later assess the IL31 immunostaining. All the reactions were followed out by positive controls (primary antibody in mouse spleen sample) and negative controls (omission of the primary antibody in canine skin samples).

Immunostaining of IL-31was assessed for the number of cells stained in the epidermis and dermis in 10 fields of each sample, followed by the total of all values. Despite being specific, the IL-31 labeling in the cytoplasm of the keratinocytes and endothelial cells was not considered on the account due to represent areas of less intense and constant immunostaining, independent of the number of lymphocytes, plasma cells and eosinophils, which exhibit strong cytoplasmic staining; and are therefore, considered as accountable for the IL-31 action.

Utilizing an optical microscope and the image capture and analysis system (DM 4000 and Leica Application Suite, Leica Microsystems, Germany) the images to count the mast cells and IL31 immunolabelled cells were obtained. The findings were listed in the Excel program and evaluations were done using the $\mathrm{R}$ program (CORE TEAM, 2016), with the ds (ARNHOLD, 2014) and easynova (ARNHOLD, 2013) packages for the Kruskal-Wallis tests and Spearman correlation between variables. Findings were considered significant when $\mathrm{p} \leq 0.05$. The correlation was considered positive when the $r$ value fell between 0 and 1 (up to $0.39=$ weak; 0.4 to $0.69=$ moderate; and 0.7 to $1=$ strong $)$ and negative when $\mathrm{r}$ was between 0 and -1 (up to $-0.39=$ weak; -0.4 to $-0.69=$ moderate; and -0.7 to $-1=$ strong $)$.

\section{RESULTS}

The present study included 31 dogs with CAD, from 12 different breeds (Shi-Tzu, $\mathrm{n}=14$, Teckel, $\mathrm{n}=3$, Lhasa Apso, $\mathrm{n}=3$, Golden Retriever, $\mathrm{n}=2$, Bull Terrier, $\mathrm{n}=2$; French Bulldog, $\mathrm{n}=1$; Beagle, $n=1$; Poodle, $n=1$; Scottish, $n=1$; Shar Pei, $n=1$; York Shire, $\mathrm{n}=1)$, with 11 males( $\mathrm{n}=11,35.5 \%)$, and 20 females $(n=20,64.5 \%)$, with a mean age of 3.7 years $(\mathrm{min}=1$ year, $\max =8$ years $)$ and median of three years.

For mast cell count identified by toluidine blue staining, the control group dogs revealed an average of seven cells in the axillary region and 11 in the interdigital areas. These values are lower than those identified in the discretely compromised dogs, which possessed 30 cells in the axillary and 31 cells in the interdigital regions. The mean number of mast cells in both regions was observed to rise in relation to the increase in the lesion score, with the highest value noted in the interdigital areas $(\mathrm{P}=0.0380)$ of the animals with markedly compromised CAD. However, although no difference in the number of mast cells was seen in the axillary region between the lesion score groups $(p=0.2219)$, in the interdigital region the dogs with marked clinical scores showed significantly higher numbers of mast cells when compared with the other dog groups affected with CAD (Table 2).

The specific IL-31 immunostaining was cytoplasmic and accentuated in the dermal inflammatory infiltrate cells, composed mostly of lymphocytes and plasma cells. The control group revealed a very much lower mean number of IL31 immunolabelled cells when compared with the 
Table 2 - Mean and median numbers of the mast cells and cells immunolabelled for IL-31 in the skin of the axillary and interdigital regions linked to the clinical score of lesion severity in dogs experiencing atopic dermatitis.

\begin{tabular}{|c|c|c|c|c|}
\hline \multirow{2}{*}{ Variable } & \multicolumn{3}{|c|}{ 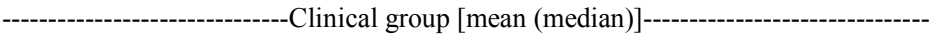 } & \multirow{2}{*}{$\mathrm{P}$} \\
\hline & Discrete & Moderate & Accentuated & \\
\hline Mast cells in axilla & $30.33(23)^{\mathrm{a}}$ & $45.94(23)^{\mathrm{a}}$ & $54.82(56)^{\mathrm{a}}$ & 0.22 \\
\hline Mast cells in interdigit & $31.00(26)^{b}$ & $35.53(33)^{b}$ & $72.91(59)^{\mathrm{a}}$ & 0.03 \\
\hline Interleukin in axilla & $81.33(100)^{\mathrm{a}}$ & $144.65(118)^{\mathrm{a}}$ & $197.91(152)^{\mathrm{a}}$ & 0.28 \\
\hline Interleukin in interdigit & $75.67(49)^{\mathrm{a}}$ & $72.12(67)^{\mathrm{a}}$ & $120.18(90)^{\mathrm{a}}$ & 0.17 \\
\hline
\end{tabular}

animal group that was mildly compromised by CAD, both in the axillary (mean $=3$ ) and interdigital $($ mean $=3$ ) regions. Also, despite the absence of any statistical difference between the clinical score groups for IL-31 immunolabelling in the axillary and interdigital areas, the highest mean value of the IL-31 positive cells was observed in the axillary $(\mathrm{P}=0.282)$ area, in the dogs severely compromised by CAD. On comparing the number of mast cells and IL-31 immunolabelled cells in the axillary and interdigital regions of the animals with $\mathrm{CAD}$, no significant difference was noted in terms of the number of mast cells in the axillary and interdigital locations. However, the number of cells immunolabelled for IL31 showed a substantial increase in the axillary skin than in the interdigital (Table 3). Figure 2 displays the mast cells and inflammatory cells labeled with toluidine blue staining and immunohistochemistry for IL-31, respectively.

The Spearman's correlation test revealed that for the variables clinical score CADESI-4 (C), number of mast cells (M) and immunolabelled (I) cells for IL-31 in axillary (a) and interdigital (i) areas of the animals affected by CAD, a correlation was present between clinical score and number of mast cells in the interdigital region $(\mathrm{P}=0.0112)$, as well as between clinical score and number of cells immunolabelled for IL-31 in the axillary skin $(\mathrm{P}=0.0156)$. The correlation between clinical score and the immunostaining for IL-31 in the interdigital skin showed a value of $p=0.05$. A significant correlation

Table 3 - Comparison between the quantity of mast cells and cells immunolabelled for IL-31 depending upon the anatomical sites of the skin of dogs suffering with atopic dermatitis.

\begin{tabular}{lccc}
\hline Variable & Axilla & Interdigit & $\mathrm{P}$ \\
\hline Mast cells & $47.5806(24)^{\mathrm{a}}$ & $48.3548(43)^{\mathrm{a}}$ & 0.43 \\
Interleukin 31 & $157.4194(114)^{\mathrm{a}}$ & $89.5161(70)^{\mathrm{b}}$ & $<0.01$ \\
\hline
\end{tabular}

$(\mathrm{P}<0.01)$ was seen between the number of mast cells in the axillary and interdigital skin. Furthermore, correlation was noted between number of mast cells and IL-31 immunolabelled cells in the axillary region $(\mathrm{P}<0.01)$. However, this correlation was absent in the interdigital skin $(\mathrm{p}=0.1596)$, as shown in table 4 . No correlation was observed between severity of pruritus and the number of IL-31-immunolabelled cells in the axillary $(\mathrm{P}=0.3491)$ and interdigital $(\mathrm{p}=0.6775)$ areas.

\section{DISCUSSION}

Although this study did not identify any correlation between pruritus and the quantity of IL31 immunolabelled cells, this cytokine is known to induce pruritus and could possibly be high in dogs that are affected with atopic dermatitis, but fail to exhibit cutaneous lesions, as demonstrated by GONZALES et al., (2016). However, positive correlations were found between the clinical score and number of mast cells, as well as between clinical score and number of cells immunolabelled for IL-31, which is an indicator of the influence these immunological constituents exert on the symptoms and lesions. Therefore, since IL-31 is related to the induction of pruritus in dogs, its increase in animals with higher lesion scores may result in increased pruritus and, consequently, exacerbation of lesions.

The lower numbers of mast cells present in the skin of healthy dogs is accepted as normal, as noted in dogs of the control group in this investigation. However, the number of cells may differ based on the location, as confirmed by AUXILIA \& HILL (2000), who reported a greater number of mast cells in the interdigital regions.

The high lesion scores in the axillary and interdigital areas in dogs having substantial numbers of mast cells signifies the active role played by these cells in the immunopathogenic process of the disease, and both the anatomical sites experience the same degree of immunological influence. These 


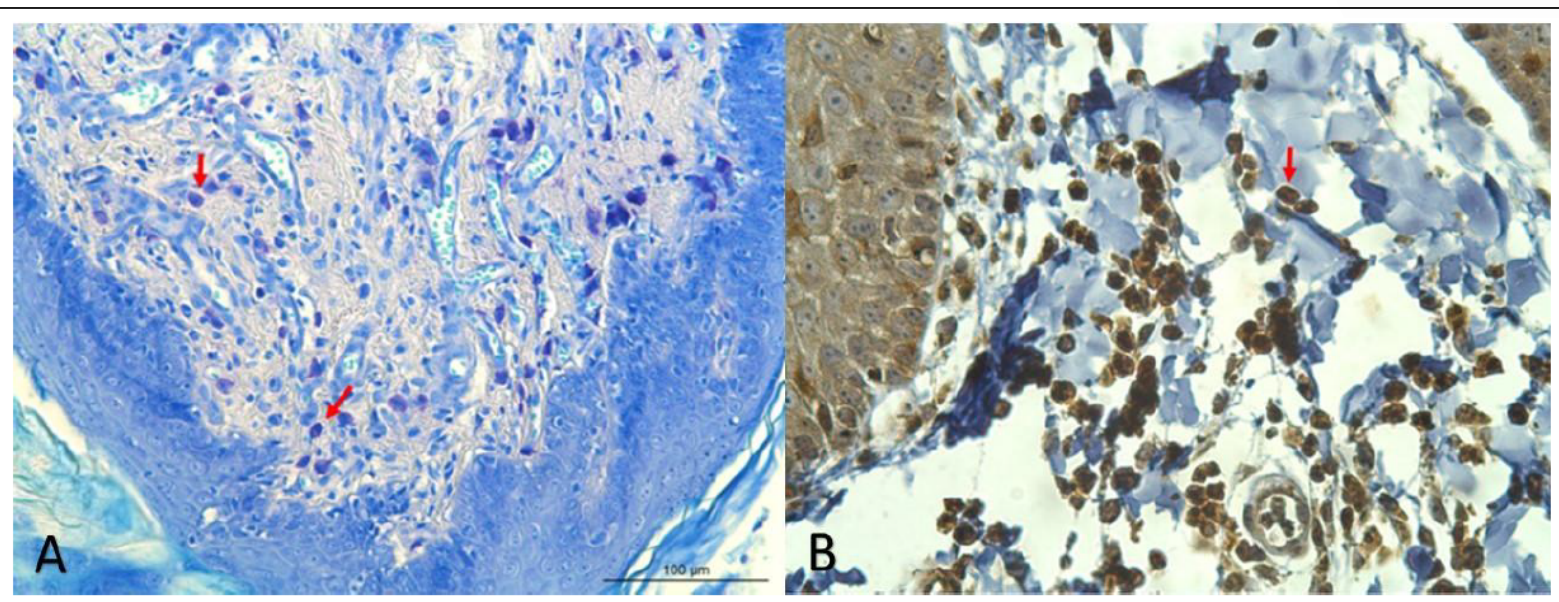

Figure 2 - Photomicrographs of the skin in the axillary region of dogs having atopic dermatitis on a marked clinical score. A) Mast cells revealing metachromatic cytoplasmic granules (arrows) to the blue color of the toluidine, 200x. D) Inflammatory cells with cytoplasmic immunostaining for anti-IL-31(arrow), 400x.

cells were also observed to exert their influence during the course of atopic dermatitis because of the steady rise in the number of mast cells evident in the various lesion scores recorded in relation to the dogs assessed, concurring with the observations made by KATO et al. (2014) in human patients. On the contrary, some animals exhibiting lower numbers of mast cells registered high lesion scores, indicating that dogs with atopic dermatitis exhibit cutaneous hyperreactivity and exacerbated response to external stimuli (DEMORA, 1996).

In this study, the detection of IL-31 positive immunostaining in the skin of dogs affected with CAD reiterates its active participation in the pathogenesis of this disease and agrees with the findings of KATO et al. (2014). These researchers discovered that human patients with atopic dermatitis showed high clinical score values, as well as high IgE in the serum and IL-31immunolabeling in the cells of the skin samples.

In the comparison made among the discrete, moderate and accentuated dog groups, the number of cells positively immunolabelled for IL31 in the axillary skin was seen to rise, implying a stronger IL-31 expression in the dogs exhibiting greater exacerbation of the clinical lesions. This fact emphasizes the significance of this interleukin in disease progression, as also noted by NEIS et al., (2006) and DILLON (2004) in mice and humans, which revealed high atopic eczema and intense pruritus linked to the heightened IL-31 expression. Also, in their study, MARSELLA (2017) reported a positive correlation between the IL-31 concentration in the serum of Beagle dogs affected with CAD, as well severity of the cutaneous lesions.

Dogs with atopic dermatitis showed higher numbers of mast cells and IL-31 immunolabelled cells in the axillary and interdigital areas for all the lesion scores. From the correlation noted between the number of mast cells and IL-31, the link between this cytokine and the presence of mast cells can be deduced. Similar to the condition noted for the other leukocytes, in this study the mast cells revealed IL31 in their cytoplasm, confirming the results of ISHII

Table 4 - Correlation between the clinical score (C), number of mast cells (M) and IL-31 (I) in the axillary skin (a) and interdigital skin (i) in dogs having atopic dermatitis.

\begin{tabular}{ccccccccc}
\hline & $\mathrm{C} / \mathrm{Ma}$ & $\mathrm{C} / \mathrm{Mi}$ & $\mathrm{C} / \mathrm{Ia}$ & $\mathrm{C} / \mathrm{Ii}$ & $\mathrm{Ma} / \mathrm{Mi}$ & $\mathrm{Ma} / \mathrm{Ia}$ & $\mathrm{Mi} / \mathrm{Ii}$ & $\mathrm{Ia} / \mathrm{Ii}$ \\
\hline $\mathrm{r}$ & 0.3169 & $0.4496^{\text {cr }}$ & $0.4304^{\text {cr }}$ & 0.3421 & $0.5986^{\text {cr }}$ & $0.506^{\text {cr }}$ & 0.2589 & 0.2714 \\
$\mathrm{p}$ & 0.08 & 0.01 & 0.01 & 0.05 & $<0.01$ & $<0.01$ & 0.15 & 0.13 \\
\hline
\end{tabular}


et al. (2009) and NIYONSABA et al. (2010). In this context, it is evident that the higher the number of mast cells along with the other leukocytes, the more the action potential of IL-31 in the CAD lesion sites, the stronger the severity of the stimulus to pruritus and thus, the greater the clinical scores of the lesions.

\section{CONCLUSION}

Mast cells and IL-31 directly participate in the pathogenesis of CAD, as well as lymphocytes and plasma cells. Also, the greater the intensity of the clinical severity of the disease, the more the quantity of the mast cells and IL-31 in the skin of the dogs having CAD, which implies the influence of these immunological constituents on the genesis of pruritus and disease progression.

\section{ACKNOWLEDGEMENTS}

The authors are grateful to the Coordenação de Aperfeiçoamento de Pessoal de Nível Superior (CAPES) for the master scholarship to Bárbara Hess Rodrigues Gonçalves.

\section{DECLARATION OF CONFLICTING INSTERESTS}

The authors declare no conflict of interest. The founding sponsors had no role in the design of the study; in the collection, analyses, or interpretation of data; in the writing of the manuscript, and in the decision to publish the results.

\section{REFERENCES}

ABBAS, A.K. et al. Imunologia molecular e celular, $6^{a}$ ed. Rio de Janeiro: Elsevier Brasil, 2006.

ARNHOLD E. Package in the $\mathrm{R}$ environment for analysis of variance and complementary analyses. Brazilian Journal of Veterinary Research and Animal Science, v. 50, n. 6, p. 488492, 2013. Available from: <http://doi.org/10.11606/issn.16784456.v50i6p488-492>. Accessed: Nov. 10, 2014. doi: 10.11606/ issn.1678-4456.v50i6p488-492.

ARNHOLD E. Package in R environment to automate descriptive reports. Sigmae, v.3, n. 1, p.36-42, 2014

AUXILIA, S. T.; HILL, P.B. Mast cell distribution, epidermal thickness and hair follicle density in normal canine skin: possible explanations for the predilection sites of atopic dermatitis? Veterinary Dermatology, v. 11, n. 4, p. 48-53, 2000. Available from: $<$ https://doi. org/10.1046/j.1365-3164.2000.00193.x>. Accessed: Feb. 15, 2015. doi: 10.1046/j.1365-3164.2000.00193.x.

DEMORA, F. et al. Skin mast cell releasability in dogs with atopic dermtitis. Inflammation Research, v. 45, n. 8, p. 424-427, 1996. Available from: $<$ http://doi.org/10.1007/BF02252939>. Accessed: Oct. 01, 2014. doi: 10.1007/BF02252939.

DILLON, S. R. et al. Interleukin 31, a cytokine produced by activated T cells, induces dermatitis in mice. Nature immunology, v. 5, n. 7, p. $752-760,2004$. Available from: $<$ https://doi.org/10.1038/ni1084>. Accessed: Jan. 10, 2015. doi: 10.1038/ni1084.

FAVROT, C. et al. A prospective study on the clinical features of chronic canine atopic dermatitis and its diagnosis. Veterinary dermatology, v. 21, n. 1, p. 23-31, 2010. Available from: <https:// doi.org/10.1111/j.1365-3164.2009.00758.x>. Accessed: Jan. 21, 2015. doi: $10.1111 / \mathrm{j} .1365-3164.2009 .00758 . \mathrm{x}$

GONZALES, A. J. et al. IL-31-induced pruritus in dogs: a novel experimental model to evaluate anti-pruritic effects of canine therapeutics. Veterinary dermatology, v. 27, n. 1, p. 34, 2016. Available from: <https://doi.org/10.1111/vde.12280>. Accessed: Oct. 10, 2016. doi: 10.1111/vde. 12280 .

HENSEL, P. et al. Canine atopic dermatitis: detailed guidelines for diagnosis and allergen identification. BMC veterinary research, v. 11, 2015. Available from: <https://doi.org/10.1186/s12917-0150515-5> . Accessed: Jul. 02, 2016. doi: 10.1186/s12917-015-0515-5.

HILL, P. B.; LAU, P.; RYBNICEK, J. Development of an ownerassessed scale to measure the severity of pruritus in dogs. Veterinary dermatology, v. 18, n. 5, p. 301-308, 2007. Available from: $<$ https:// doi.org/10.1111/j.1365-3164.2007.00616.x>. Accessed: Jun. 02, 2016. doi: 10.1111/j.1365-3164.2007.00616.x.

ISHII, T. et al. Pivotal role of mast cells in pruritogenesis in patients with myeloproliferative disorders. Blood, v. 113, n. 23 , p. 5942-5950, 2009. Available from: <http://doi.org/10.1182/ blood-2008-09-179416>. Accessed: Oct. 10, 2016. doi: 10.1182/ blood-2008-09-179416.

KATO, A. et al. Distribution of IL-31 and its receptor expressing cells in skin of atopic dermatitis. Journal of dermatological science, v. 74, n. 3, p. 229-235, 2014. Available from: $<$ https://doi. org/10.1016/j.jdermsci.2014.02.009>. Accessed: Oct, 12. 2016. doi: 10.1016/j.jdermsci.2014.02.009.

MARSELLA, R. et al. Investigation of the correlation of serum IL-31 with severity of dermatitis in an experimental model of canine atopic dermatitis using beagle dogs. Veterinary Dermatology, v. 28, n. 1, p. 441-442, 2017. Available from: $<$ https://doi.org/10.1111/ vde.12500>. Accessed: Jul. 14, 2016. doi: 10.1111/vde.12500.

MURPHY K. Imunobiologia de Janeway. $7^{\text {a }}$ ed. Porto Alegre: Artmed, 2010.

NEIS, M.M. et al. Enhanced expression levels of IL-31 correlate with IL-4 and IL-13 in atopic and allergic contact dermatitis. Journal of Allergy and Clinical Immunology, v. 118, n. 4, p. 930-937, 2006. Available from: <https://doi.org/10.1016/j.jaci.2006.07.015>. Accessed: Sept. 14, 2015. doi: 10.1016/j.jaci.2006.07.015.

NIYONSABA, F. et al. Antimicrobial peptides human $\beta$-defensins and cathelicidin LL-37 induce the secretion of a pruritogenic cytokine IL-31 by human mast cells. The Journal of Immunology, v. 184, n. 7, p. 35263534, 2010. Available from: $<$ http://doi.org/10.4049/jimmunol.0900712>. Accessed: Jan. 15, 2015. doi: 10.4049/jimmunol.0900712.

OLIVRY $\mathrm{T}$. et al. The ACVD task force on canine atopic dermatitis: forewords and lexicon. Veterinary immunology and immunopathology, v. 81, p. 143-146, 2001. Accessed: Jan. 12, 2015. doi: 10.1016/S0165-2427(01)00343-9.

OLIVRY, T. et al. Treatment of canine atopic dermatitis: 2010 clinical practice guidelines from the international task force

Ciência Rural, v.48, n.9, 2018. 
on canine atopic dermatitis. Veterinary dermatology, v. 21, n. 3, p. 233-248, 2010. Available from: <https://doi.org/10.11 11/j.1365-3164.2010.00889.x>. Accessed: Jan. 15, 2016. doi: 10.1111/j.1365-3164.2010.00889.x.

OLIVRY, T.et al. Validation Of The Canine Atopic Dermatitis Extent and Severity Index (CADESI)-4, a simplified severity scale for assessing skin lesions of atopic dermatitis in dogs. Veterinary Dermatology, v. 25, n. 2, p. 77, 2014. Available from: $<$ https://doi. org/10.1111/vde.12107>. Accessed: Feb. 03, 2015. doi: 10.1111/ vde. 12107 .

PUCHEU-HASTON, C. M. et al. The role of antibodies, autoantigens and food allergens in canine atopic dermatitis.
Veterinary Dermatology, v. 26, n. 2, p. 115, 2015. Available from: $<$ https://doi.org/10.1111/vde.12201>. Accessed: Jul. 13, 2015. doi: $10.1111 /$ vde. 12201 .

SPERGEL, J. M. et al. Roles of TH1 and TH2 cytokines in a murine model of allergic dermatitis. Journal of Clinical Investigation, v. 103, n. 8 , p. $1103-1111,1999$. Available from: <https://doi.org/10.1172/ JCI5669>. Accessed: Jan. 30, 2016. doi: 10.1172/JCI5669.

WOLF, R.; WOLF, D. Abnormal epidermal barrier in the pathogenesis of atopic dermatitis.Clinics in dermatology, v. 30, n. 3, p. 329-334, 2012. Avaliable from: <https://doi.org/10.1016/j. clindermatol.2011.08.023>. Accessed: Feb. 05. 2015. doi: 10.1016/j.clindermatol.2011.08.023. 